\title{
Design Mobile Learning Application with Performance-Based Authentic Assessment as A Remote Learning Tool for Higher Education
}

\author{
*Madziatul Churiyah, Universitas Negeri Malang, Indonesia, madziatul.churiyah.fe@um.ac.id \\ Andi Basuki, Universitas Negeri Malang, Indonesia \\ Buyung Adi Dharma, Universitas Negeri Malang, Indonesia \\ Filianti, Universitas Negeri Malang, Indonesia \\ Dewi Ayu Sakdiyyah, Universitas Negeri Malang, Indonesia
}

\begin{abstract}
The rapid development of digital technology demands that learning activities as the heart of lectures metamorphose towards digital technology-based learning that is easily accessible to students as Generation Z, which is digital native. This study aims to develop a mobile learning application (MLA) that features authentic performance-based assessment so that students have 21st Century Skills. The developed MLA is used as one of the tools in remote learning activities in higher education in Indonesia. Features in this MLA include material in the form of text, video, and link integration in wider material resources, video-conferencing and evaluation. Through validation activities by material experts and media experts, the results of this study indicate that the MLA design is very feasible to be used as one of the remote learning tools in higher education so it needs to be implemented on a broader subject for students in Indonesia.
\end{abstract}

Keywords: Mobile learning application, Higher education, Remote learning, Performance-based authentic assessment.

$$
\text { Received: 07.12.2020 }
$$$$
\text { Accepted: } 10.01 .2021
$$$$
\text { Published: 02.02.2021 }
$$

\section{INTRODUCTION}

The rapid development of technology has an impact on various aspects of life, including higher education. The existence of the industrial revolution also contributed to the digitalization of higher education in the current era [11][16]. In the midst of the discussion of the Industrial Revolution 4.0 which is currently developing, the last few years the concept of Society 5.0 brought about by Japan has also emerged and this has strengthened all elements of society including higher education who are progressing in thinking of smart education-based education services that utilize the development of digital technology [20]. Based on this, then virtual and physical space collaboration needs to be done in order to create technologybased learning that provides social benefits [6].

Students in the current era are generation Z, native digital figures are that almost all of their activities are supported by smartphone access, ranging from communication, shopping, looking for entertainment, to finding learning information [49]. It is undeniable that smartphones do provide students the opportunity to learn in a fun way through a digital technology approach [1][23]. The sophistication of smartphone technology is able to facilitate students in supporting their studies, ranging from finding lecture material, communicating with lecturers, conducting distance lectures (videoconference) to making a simple work such as photo editing, vlogs and so on. But it must be admitted that this is not the maximum achievement because there is no system (software) that accommodates the implementation of learning through an integrated smartphone. This makes students too free-flowing in the vastness of information available on the internet so that sometimes it makes them confused and out of control in determining the truth-confirmed knowledge. This kind of event encourages the development of a software that supports student learning activities, both for one particular subject or a combination of several subjects.

This can be dealt with by building a Mobile Learning Application (MLA) that presents material resources in a comprehensive and extensive manner and has interesting features that can support the success of student lectures. Some researchers revealed that mobile learning refers to a cross-context learning model, through interactions using personal electronic devices [15], in this case as in the use of mobile phones, tablets and laptops for teaching and learning purposes [43]. This means that mobile learning is an extension of distance education supported by mobile devices equipped with wireless 
technology [37]. Based on this, MLA can be interpreted as a software available on the Android platform, iOS, and other platforms that can be downloaded via the internet network [14]. This application serves students (users) as a study guide tool during their studies [25].

In Indonesia, efforts to digitize higher education have been running through regulations from the ministries in charge of higher education, for example Permendikbud 109/2013 on Organizing Distance Education in Higher Education which encourages universities in Indonesia to adopt the concept of distance learning and e-learning. In addition, the development of e-learning platforms has also been built by universities in Indonesia to facilitate students and lecturers in implementing distance learning practices for certain subjects [31]. Unfortunately for the MLA case, it has not yet been found in Indonesian universities, including those in the S1 Office Administration Education Program (PADP) which are widely available at universities in Indonesia. This resulted in the absence of systematic learning facilities through smartphone devices by students. The impact, learning activities via smartphones are less than optimal. Based on this, the opportunities and demands of digital life need to be developed in an MLA [5][12][21][32].

This study aims to develop an MLA in the 'Filing' Course for PADP undergraduate students in Indonesia which will function as a tool in implementing remote learning. The developed application has various features ranging from login profile where students can fill in their identities as users, application usage instructions, a collection of material in the form of text and images, videos, authentic performancebased assessments so that students have 21st Century Skills, chatrooms to facilitate student-lecturer communication and student to student, and video-conferencing to conduct face-to-face learning from distance to reporting to lecturers. This MLA development is very important because students here as native digital residents need to be given a learning approach that is appropriate to their characteristics [1][4][29][49]. In addition, in the 'Archives' course that researchers developed, there is a lot of material that is abstract so that it requires a comprehensive visual explanation. Indonesia that adopts the 21st Century Skills concept must also begin to transform higher education learning into a systematic digital learning system that can be operated on students' mobile devices (smartphones) [3].

Along with the covid-19 pandemic phenomenon that forced the replacement of physical classes into virtual forms, the term remote learning began to be re-discussed. Simply stated, remote learning is a learning activity using the internet and technology and all learning activities are carried out remotely without any traditional class elements. Through this, lecturers can provide very extensive lecture material resources either through TV shows, e-books, videos on the internet so that the most likely to integrate many resources is MLA [38]. The implementation of remote learning can be done synchronously or asynchronously.

\section{LITERATURE REVIEW}

\section{Why Mobile Learning Application for Higher Students}

The technology-based learning model has begun to develop since the increase in smartphone users in daily activities. Through the use of MLA, it allows learning activities carried out at different times and places [37]. Until now, many research findings reveal that the use of smartphones as access to learning through MLA can improve the quality of learning in higher education environments [21]. For example, Ghareb's research developing android applications for telecommunications engineering courses [19], Yassine in informatics engineering courses [49], Bhatheja in medical courses [8], and Kattayat in applied physics [27]. Al-Emran also examined that the application of MLA helps students and lecturers in completing assignments at short meetings and can be done anywhere and anytime [5]. Other research by Lestari concluded that the use of MLA has a positive influence on student academic achievement [32]. Likewise, Chavoshi who developed MLA for universities in Iran and stated that MLA allows students to be active participants and not just be passive recipients of knowledge [12].

The use of MLA in the learning process is not only influenced by the increasing use of smartphones in the last few decades, but is also caused by the development of the current industrial revolution which has entered the 4.0 era [16]. So that all activities that were originally carried out manually or conventionally began to be done using technology, one of which was in terms of education [40]. In education in the 4.0 era, learning was connected to students with a focus on students, aimed at students and led by students [32]. In addition to the industrial revolution 4.0 there are also other things that have led to an increase in technological development in the world of education, namely society 5.0 (super smart society) which was initiated by the Japanese State [18]. The idea that underlies the society 5.0 program is the rapid development of information technology that enables the combination of cyberspace, information with the physical and real world [35]. This concept makes it possible to use 
modern science (AI, robot, IoT, etc.). This is expected to bring major changes to society because of the use of modern technology that relies on humans as its main component.

The use of MLA is important to be applied in higher education given that global competition is getting tougher and the ability of students who are considered readier to apply MLA in the learning process [36]. Through the application of MLA in higher education is expected to increase student involvement in the learning process and is an appropriate response in facing the development of the characteristics of today's students.

\section{Higher Education Students are Digital Native}

Entering the digital era as it is now, people are increasingly easy to carry out various activities such as conducting communication, working, and studying. The generation that grew up in the digital era is called digital native [45]. Digital native is an experienced technology user who understands technology inherently and behaves and thinks differently because of the use of the technology [24]. Helsper \& Eynon in his research stated that digital native is a young generation born when the internet has become a part of their lives [22]. Their lives have been surrounded by the internet since they were still in the womb until the beginning of their birth. So that the display of newborn photos, which are attributed in cyberspace becomes part of digital native.

Current students are digital natives who tend to carry out various activities through digital media [44]. They often use technology and have no difficulty using it [15]. With this, educators and policy makers must pay attention to digital digital characteristics when designing the materials and teaching methods used [4]. The latest data from Google Consumer Behavior written by Kemp states that Indonesia, whose total population is 265.4 million, has $50 \%$ of internet users [28]. Half of the internet users are digital natives. Meanwhile, according to Stat Counter Global Stats, android users reached $92.65 \%$ while iOS was 7.16\% [41][45]. Based on these data the researcher intends to develop an Android-based MLA in the 'Filing' Course.

\section{Learn from Covid-19 Pandemic}

The concept of the Industrial Revolution 4.0, which was adopted by many countries in the world including Indonesia and Society 5.0 brought by Japan, really attracted higher education so that it would immediately make efforts to digitize education. In addition to this choice felt more in line with the characteristics of today's students who are digit [49], various benefits are also obtained such as saving more time in carrying out learning, and being able to provide a more meaningful learning experience [45][50]. Unfortunately, not a few who reject this idea by questioning the effectiveness of the implementation of online lectures in building student character and skills needed in each study program [17]. This kind of argument can be judged as premature because education digitalization is a necessity in the current era. The provision of skills through online lectures can actually be pursued by developing a quality platform and in accordance with learning needs.

In early 2020, various world activities were forced to stop due to the Covid-19 pandemic (Coronavirus Disease-2019), a virus that was first discovered in Wuhan, Hubei, China around the beginning of December 2019 [2][39]. Like it or not, ready or not ready, activities in higher education were diverted towards distance learning by utilizing technology. Even though the world stops at an unpredictable time until now, teaching at universities must continue to consider that education is the strongest predictor of health and wealth for a country's future human resources [48]. In this difficult situation the Covid-19 pandemic, Chick et al. recommends the use of high-level technology that is easily accessible to students to provide practical experience remotely to support the skills needed for certain study programs [13]. Indeed, this kind of thing will be difficult, but the situation and conditions force it all. Thereby encouraging the creation of digital technology-based learning media that are low-tech in order to be easily accessed by students, some of whom live in rural areas so that they have limited high-speed internet networks [46].

The support for the use of digital technology to conduct learning in high education has also been supported by UNESCO, which in 2009 the world agency recommended governments in various countries including Indonesia to adopt this technology to create educational inclusion [9]. Through the Covid-19 pandemic that is currently happening, efforts to digitize education must be taken seriously and all elements concerned must immediately understand the nature of education digitalization including to appear efforts to build platforms / software / tools that can accommodate these needs. 


\section{RESEARCH METHODS}

This research was conducted due to the development of the characteristics of current students and the opportunities for technological development are very abundant. This type of research is a Resource \& Development consisting of three phases, namely:

\section{Initial Research: Conducting Field Studies and Literature Studies}

The first phase is carried out by analyzing technological developments, the curriculum that applies to the Office of Administrative Education Bachelor program in Indonesia which only exists in three Indonesian tertiary institutions namely Malang State University, Indonesian University of Education, and State University of Makassar, and analyzing the availability of supporting learning possessed students as well as universities. In addition, an analysis of the development of students in general in Indonesia was also conducted in order to achieve product accuracy in accordance with their conditions.

Krull \& Duart and Pimmer et al. review articles that discuss the development of mobile learning research in higher education environments and mention that what remains an issue is an inadequate assessment format and tends to be less effective [30][38]. Based on this, in MLA which is then given the name Ficoura (Filing Course Application) added a special assessment menu in the form of authentic performance-based assessment that can support students to have 21st Century Skills.

\section{Product Development}

After conducting field studies and literature, in this second phase we began to develop Ficoura with the intention of making it one of the tools in carrying out remote learning activities in the college environment. This is done because we realize that in the current era, the use of MLA is not the only learning tool that is able to accommodate all student learning activities. The use of Ficoura in remote learning activities will help lecturers and students gain meaningful learning experiences with extensive material resources.

\section{Product Validation}

In the third phase, the product that was developed was validated by two validators, namely an MLA expert and a material expert in relation to the MK Filing System. Figure 1 below explains the flow of this study in general.

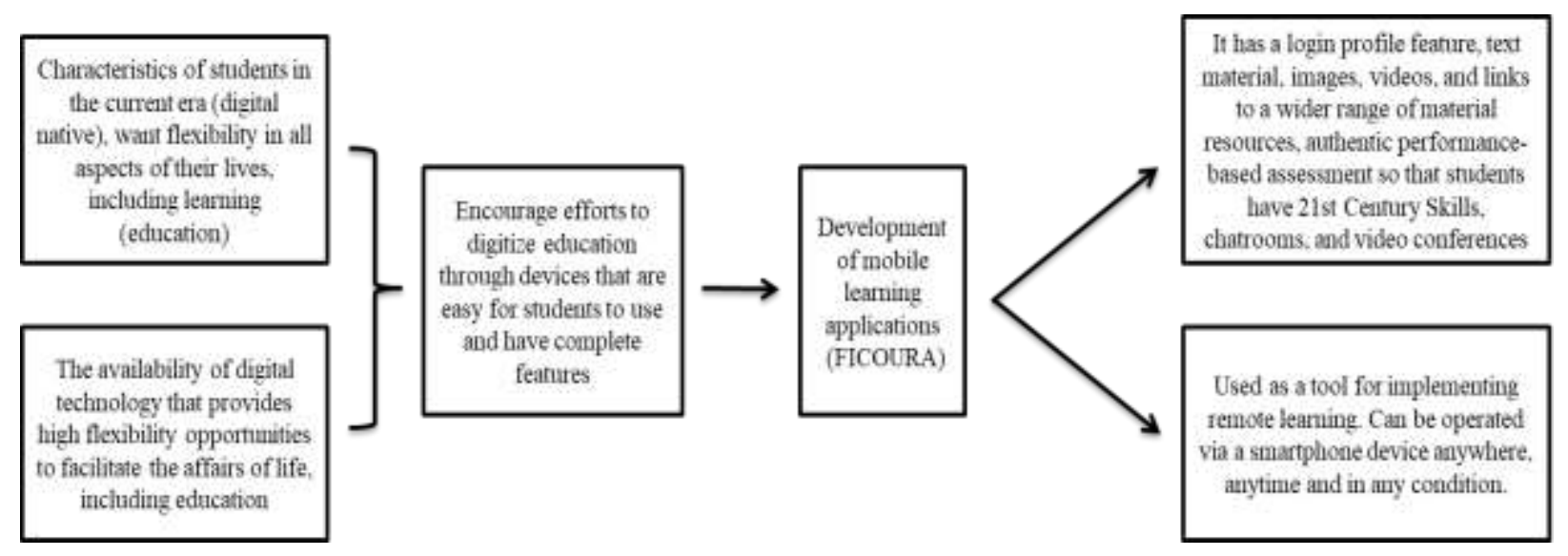

Figure 1. Chart of Ficoura's MLA development path (Filing Course Application)

\section{RESEARCH FINDINGS AND DISCUSSION}

The purpose of this research is to develop an MLA product that is used by students in the Filing Management course. The MLA product, which is then named Ficoura (Filing Course Application), can be downloaded at the Google Play Store and can be operated on all versions of Android. Ficoura was built using Android Studio software with other support software such as Corel Draw for designing templates, and Wonder share Filmora for editing videos in the application.

During this time the development of MLA for universities is constrained in the assessment aspects. Where assessment is given only in the cognitive domain which lacks meaningful results in student learning outcomes [38]. While in the world of lectures, psychomotor aspects are very important to be used as a way to see the ability of students to implement the knowledge that has been learned [47]. 
At Ficoura, we add a special feature that is performance-based authentic assessment that is in accordance with the characteristics of the Filing Management Course available at higher institutions in Indonesia.

Ficoura has the following features:

a. Introducing Ficoura. This feature is to introduce Ficoura to users. After that, there is a login profile section so that students enter their academic identity to facilitate their learning activities in the Ficoura application.

b. Menu. The page that presents menus to get to the features in the Ficoura application.

c. Hint. On this menu there are technical instructions for using the Ficoura application.

d. CPMK. Course Learning Outcomes, contain points that students must achieve after carrying out learning using this Ficoura application.

e. Theory. Material in Ficoura consists of material in the form of text and images, link resource material on web pages and videos. Students can learn as much material as possible and they will get real examples of archiving practices through the video material in this Ficoura application.

f. Meeting. The feature to carry out face-to-face learning remotely, while this feature is an integration feature on the ZOOM application which is commonly used in carrying out video conferencing.

g. Evaluation. Assessment features, namely performance-based authentic assessment that can support students in having 21st Century Skills that are needed in the current era.

h. Closing. Contains concluding greetings, developer information and reference material list in this Ficoura application.

The following are some screenshots of the Ficoura application.

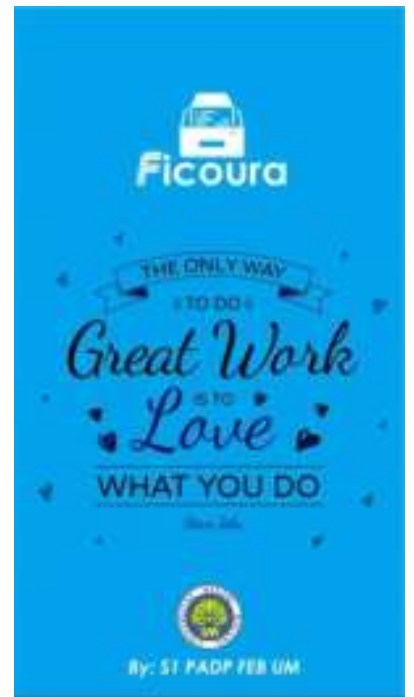

Figure 2. Display of the Ficoura start page

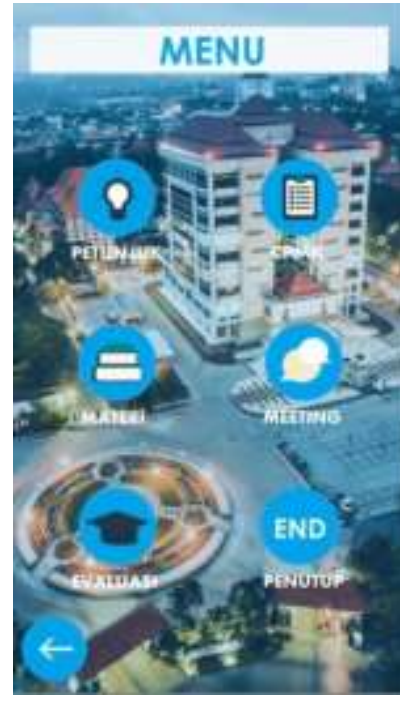

Figure 3. Ficoura menu page

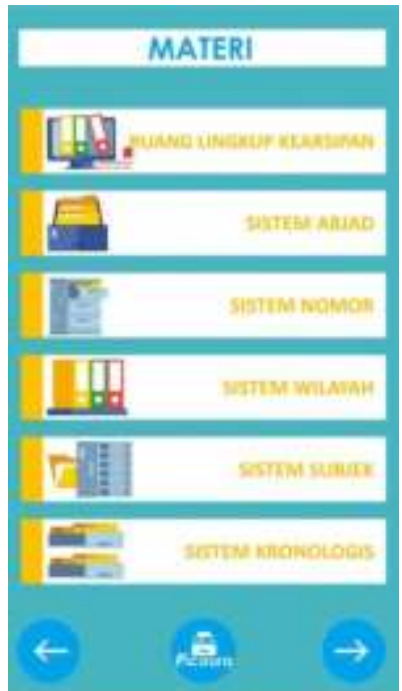

Figure 4. Display list of material in Ficoura

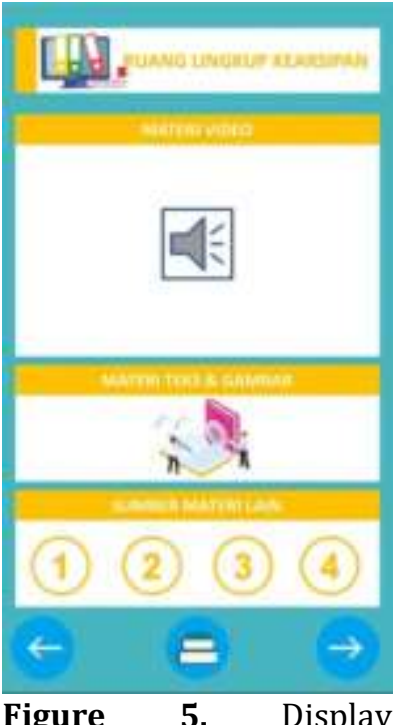

material consisting of text and image material, videos, and link resource material on the website

Students can install the Ficoura app on their Android smartphone. Then they can see the video of the introduction of this application to get an overview of the concept of the application. Furthermore, they can learn the Course Learning Outcomes of the 'Filing' Course in the Ficoura application and then fill in the login profile feature to complete their identity as a user. Ficoura is classified as a type of low-tech application where users can operate this application without having to be connected to high-speed internet. This application can also be operated on all versions of Android with a small RAM of 512 MB. With this specification, students who live in rural areas can use this application smoothly even though the Covid-19 pandemic situation is currently happening.

Students can learn all the material in this application, both theoretical and real practice examples in the form of videos. After studying all of the material, students can conduct evaluation activities in the form of authentic performance-based assessments where they are directed to make a work, which can be a vlog of the practice of implementing one of the archival management systems in the Ficoura application. In this evaluation section, students can report that they have finished working on their assignments via e- 
mail integrated with Gmail. This makes it easier for lecturers to control student attendance and measure the level of completion of assignments given to students.

The product validation process is assessed by MLA experts and material experts. The validator provides an assessment to determine whether the MLA product that has been developed is valid or not to be used as a remote learning tool. The following Table 1 explains the results of validation by MLA experts.

Table 1. Results of MLA Expert Validator assessment

\begin{tabular}{|c|c|c|c|}
\hline Aspect & Indicator & $\begin{array}{l}\text { Score } \\
\text { Obtained } \\
\text { (x) }\end{array}$ & $\begin{array}{l}\text { Ideal } \\
\text { Score } \\
\text { (xi) }\end{array}$ \\
\hline $\begin{array}{l}\text { Content } \\
\text { design }\end{array}$ & $\begin{array}{l}\text { a. Clarity of content } \\
\text { b. Conformity with learning needs } \\
\text { c. Conformity with the user's cognitive level } \\
\text { d. Organize the content in the application well } \\
\text { e. The accuracy of providing information } \\
\text { f. Appropriate text selection } \\
\text { g. Suitability of the article }\end{array}$ & $\begin{array}{l}5 \\
5 \\
4 \\
4 \\
4 \\
5 \\
5 \\
\end{array}$ & $\begin{array}{l}5 \\
5 \\
5 \\
5 \\
5 \\
5 \\
5 \\
\end{array}$ \\
\hline $\begin{array}{l}\text { Presentation } \\
\text { design }\end{array}$ & $\begin{array}{l}\text { a. Attractive graphics / images / videos in increasing user } \\
\text { interest } \\
\text { b. Attractive graphics / images / videos in improving user } \\
\text { understanding } \\
\text { c. Enjoy the appearance of the application in increasing } \\
\text { user interest } \\
\text { d. Enjoy the appearance of the application in increasing } \\
\text { user understanding } \\
\text { e. The winning content in the application attracts the } \\
\text { f. Aser's attention } \\
\text { f. Accuracy in using background music }\end{array}$ & $\begin{array}{l}4 \\
5 \\
4 \\
5 \\
5\end{array}$ & $\begin{array}{l}5 \\
5 \\
5 \\
5 \\
5 \\
5\end{array}$ \\
\hline $\begin{array}{l}\text { Interface } \\
\text { design }\end{array}$ & $\begin{array}{l}\text { a. Attractive interface design } \\
\text { b. Appropriate interface design } \\
\text { c. Consistency of text position in design } \\
\text { d. Consistent placement of graphics / images / videos in } \\
\text { the interface }\end{array}$ & $\begin{array}{l}5 \\
5 \\
4 \\
5\end{array}$ & $\begin{array}{l}5 \\
5 \\
5 \\
5\end{array}$ \\
\hline \multicolumn{3}{|c|}{$\begin{array}{ll}\text { Total } & 78 \\
\end{array}$} & 85 \\
\hline
\end{tabular}

$\begin{aligned} \text { Percentage } & =x / x i \times 100 \% \\ & =78 / 85 \times 100 \% \\ & =91 \%\end{aligned}$

Based on Table 1, MLA expert validators assess three aspects of assessment. The determination of aspects of this assessment is adjusted to the needs of each assessor of the product being developed. From the results of the calculation of the MLA expert questionnaire assessment of Ficoura that has been developed, the results are obtained by $91 \%$. For the results of expert validation, the material is presented in Table 2 below.

Table 2. Results of Expert Material Validator assessment

\begin{tabular}{|c|c|c|c|}
\hline Aspect & Indicator & $\begin{array}{l}\text { Score } \\
\text { Obtained } \\
\text { (x) }\end{array}$ & $\begin{array}{l}\text { Ideal } \\
\text { Score } \\
\text { (xi) }\end{array}$ \\
\hline $\begin{array}{l}\text { Suitability of } \\
\text { Material } \\
\text { Description }\end{array}$ & $\begin{array}{l}\text { a. Completeness of material } \\
\text { b. Extent of Material } \\
\text { c. Depth of Material }\end{array}$ & $\begin{array}{l}4 \\
4 \\
4\end{array}$ & $\begin{array}{l}5 \\
5 \\
5\end{array}$ \\
\hline $\begin{array}{l}\text { Material accuracy } \\
\text { and truth }\end{array}$ & $\begin{array}{ll}\text { a. } & \text { Filing Scope } \\
\text { b. } & \text { Filing Equipment and Supplies } \\
\text { c. } & \text { Recording, Distribution and Storage of Filing } \\
\text { d. } & \text { Filing System (Alphabetical, Chronological, } \\
& \text { Regional, Subject, Number) } \\
\text { e. } & \text { Rediscovery and Borrowing Filing } \\
\text { f. } & \text { Maintenance, Care and Security of Records }\end{array}$ & $\begin{array}{l}5 \\
5 \\
4 \\
4 \\
5 \\
5\end{array}$ & $\begin{array}{l}5 \\
5 \\
5 \\
5 \\
5 \\
5\end{array}$ \\
\hline
\end{tabular}




\begin{tabular}{|l|l|l|l|}
\hline Aspect & Indicator & $\begin{array}{l}\text { Score } \\
\text { obtained } \\
\text { (x) }\end{array}$ & $\begin{array}{l}\text { Ideal } \\
\text { Score } \\
\text { (xi) }\end{array}$ \\
\hline & g. Transfer and destruction of records & 5 & 5 \\
\hline $\begin{array}{l}\text { Supporting } \\
\text { learning material }\end{array}$ & $\begin{array}{l}\text { a. } \begin{array}{l}\text { Conformity with the development of science and } \\
\text { technology } \\
\text { according to the present conditions, features, } \\
\text { examples and references } \\
\text { c. Linkages between concepts } \\
\text { d. Enrichment }\end{array} \\
\text { Total }\end{array}$ & 4 & 5 \\
\hline \multicolumn{1}{|c|}{62} & 5 & 5 \\
\hline
\end{tabular}

$\begin{aligned} \text { Percentage } & =x / x i \times 100 \% \\ & =62 / 70 \times 100 \% \\ & =89 \%\end{aligned}$

From the results of the calculation of the questionnaire assessment by material experts on MLA that has been developed, the results obtained by $89 \%$. The results of the two tables show that the MLA that has been developed is in accordance with the eligibility criteria and can be used as a remote learning tool.

Ficoura as MLA can be used as a medium for delivering learning material, facilitating communication, and providing assessment and feedback [42]. This media can also be used to support the ability of students as digital natives to use renewable technology [44]. Ficoura has a limitation that can only be operated on an Android smartphone, so iOS users have not been able to implement MLA products that have been developed by researchers.

Ficoura was built as an effort to contribute in carrying out remote learning activities in higher education for certain situations such as the recent one, the covid-19 pandemic. Lipomi shared her experience of utilizing video learning uploaded on platforms such as YouTube as one of the teaching materials in carrying out remote learning activities during the covid-19 pandemic, this is very effective because for students today as the $\mathrm{Z}$ generation, video is a natural medium for them [33]. This is in accordance with the Ficoura application which provides material in the form of real practice videos in implementing existing filing management systems.

Efforts to use technology as a remote learning tool in recent decades have also been carried out, for example by Calvo et al. and Karakasidis who created virtual remote manufacturing cell laboratories for engineering students as a solution to overcome the problem of limited access and the number of traditional laboratories /physical [10][26]. In order to overcome the limitations of physical / traditional laboratory access to the Archives Management Course, the construction of Ficoura which presents complete material resources also greatly facilitates the implementation of remote learning. Martín developed a website for the purposes of remote learning tools in communication theory courses for students in Spain. In that case, he combined many offline and online devices to support the success of remote learning [34]. This indicates that the implementation of remote learning not only requires one tool, but can also add other tools. Like for example in the case of using Ficoura as a remote learning tool that also utilizes the ZOOM application.

The use of mobile learning devices that are easy and can be operated anywhere and anytime can assist students in maintaining the sustainability of their learning activities even without having to attend classes on campus [37]. Even in general situations, Ficoura can still be used as a tool in meaningful learning activities that are fun. Current characteristics of students who really need speed and accuracy of information through their smartphone devices can also be fulfilled by providing an MLA facility, including Ficoura where they can carry out learning activities independently and can teach their peers so as to create high-level learning activities in among students [7].

\section{CONCLUSION AND FUTURE ENHANCEMENT}

This research successfully developed Ficoura (Filing Course Application), an MLA that can be operated on all android versions by students in universities in Indonesia. Ficoura has various features that can support remote learning activities such as the availability of abundant and verified material resources, video conferencing for conducting face-to-face learning remotely, and authentic performance-based assessments so that students have 21st Century Skills. Ficoura can be used as one of the remote learning 
tools that is quite effective because it has obtained the results of validation from two experts, namely the MLA expert and the expert of subject matter of the Filling Management Course.

Seeing the situation of technological developments and times, the use of Ficoura is very important as an effort to maintain the teaching process to students, especially in the current Covid-19 pandemic situation. The abundance of features and qualified material makes it easy for students to carry out learning off campus, because Ficoura access can also be done offline so that students who are in rural areas that are difficult to get high-speed internet access can continue to carry out lectures effectively and efficiently.

This research has limitations where the Ficoura application can only be operated on an Android smartphone only, there is no version of the application for iOS. In addition, to verify further data, a largescale student trial is needed. In certain subjects, such as subjects in the scope of science and technology, the development of MLA can utilize AR technology to present a more realistic learning experience so that the learning process can run optimally even without continuous face-to-face lectures.

The effort to digitize education is not just a response to the increasingly rapid technological development, but the change in student behavior is also one of the important foundations. Moreover, the current social and cultural conditions of the people who need just-in-time information also encourage the development of MLA as an effort to digitize education. This process is not only done by self-taught where the results look like what happened in the Covid-19 crisis in 2020. It can be seen that almost all universities in Indonesia are less ready to face the implementation of distance learning. Adoption of digital learning must be done formally through government support and the availability of devices that are able to accommodate the needs of implementing meaningful learning.

\section{REFERENCES}

Acquah, E. O., \& Katz, H. T. (2020). Digital game-based L2 learning outcomes for primary through highschool students: A systematic literature review. Computers \& Education, 143, 103667. https://doi.org/10.1016/j.compedu.2019.103667

Adnan Shereen, M., Khan, S., Kazmi, A., Bashir, N., \& Siddique, R. (2020). COVID-19 infection: Origin, transmission, and characteristics of human coronaviruses. Journal of Advanced Research, S2090123220300540. https://doi.org/10.1016/j.jare.2020.03.005

Afandi, Sajidan, Akhyar, M., \& Suryandi, N. (2019). Development Frameworks of the Indonesian Partnership 21st-Century Skills Standards for Prospective Science Teachers: A Delphi Study. Jurnal Pendidikan IPA Indonesia, 8(1). https://doi.org/10.15294/jpii.v8i1.11647

Akçayır, M. (2016). What makes you a digital native? Is it enough to be born after 1980? Computers in Human Behavior, 6. https://doi.org/10.1016/j.chb.2016.02.089

Al-Emran, M., Elsherif, H. M., \& Shaalan, K. (2016). Investigating attitudes towards the use of mobile learning in higher education. Computers in Human Behavior, 56, 93-102. https://doi.org/10.1016/j.chb.2015.11.033

Al-Hunaiyyan, A., Al-Sharhan, S., \& Alhajri, R. (2017). A New Mobile Learning Model in the Context of the Smart Classrooms Environment: A Holistic Approach. International Journal of Interactive Mobile Technologies (IJIM), 11(3), 39. https://doi.org/10.3991/ijim.v11i3.6186

Ally, M., \& Prieto-Blázquez, J. (2014). Quin és el futur de l'aprenentatge mòbil en l'educació? RUSC. Revista de Universidad y Sociedad Del Conocimiento, 11(1), 142. https://doi.org/10.7238/rusc.v11i1.2033

Bhatheja, S., Fuster, V., Chamaria, S., Kakkar, S., Zlatopolsky, R., Rogers, J., Otobo, E., Atreja, A., Sharma, S. K., \& Kini, A. S. (2018). Developing a Mobile Application for Global Cardiovascular Education. Journal of the American College of Cardiology, 72(20), 2518-2527. https://doi.org/10.1016/j.jacc.2018.08.2183

Briz-Ponce, L., Pereira, A., Carvalho, L., Juanes-Méndez, J. A., \& García-Peñalvo, F. J. (2017). Learning with mobile technologies - Students' behavior. Computers in Human Behavior, 72, 612-620. https://doi.org/10.1016/j.chb.2016.05.027

Calvo, I., Marcos, M., Orive, D., \& Sarachaga, I. (2009). Building complex remote learning laboratories. Computer Applications in Engineering Education, n/a-n/a. https://doi.org/10.1002/cae.20239

Chaim, 0., Muschard, B., Cazarini, E., \& Rozenfeld, H. (2018). Insertion of sustainability performance indicators in an industry 4.0 virtual learning environment. Procedia Manufacturing, 21, 446-453. https://doi.org/10.1016/j.promfg.2018.02.143

Chavoshi, A., \& Hamidi, H. (2019). Social, individual, technological and pedagogical factors influencing mobile learning acceptance in higher education: A case from Iran. Telematics and Informatics, 38, 133-165. https://doi.org/10.1016/j.tele.2018.09.007 
Chick, R. C., Clifton, G. T., Peace, K. M., Propper, B. W., Hale, D. F., Alseidi, A. A., \& Vreeland, T. J. (2020). Using Technology to Maintain the Education of Residents During the COVID-19 Pandemic. Journal of Surgical Education, S1931720420300842. https://doi.org/10.1016/j.jsurg.2020.03.018

Cho, M.-H., \& Castañeda, D. A. (2019). Motivational and affective engagement in learning Spanish with a mobile application. System, 81, 90-99. https://doi.org/10.1016/j.system.2019.01.008

Danish, J., \& Hmelo-Silver, C. E. (2020). On activities and affordances for mobile learning. Contemporary Educational Psychology, 60, 101829. https://doi.org/10.1016/j.cedpsych.2019.101829

Darmaji, D., Kurniawan, D. A., Astalini, A., Lumbantoruan, A., \& Samosir, S. C. (2019). Mobile Learning in Higher Education for The Industrial Revolution 4.0: Perception and Response of Physics Practicum. International Journal of Interactive Mobile Technologies (IJIM), 13(09), 4. https://doi.org/10.3991/ijim.v13i09.10948

Fawns, T. (2019). Postdigital Education in Design and Practice. Postdigital Science and Education, 1(1), 132-145. https://doi.org/10.1007/s42438-018-0021-8

Fukuda, K. (2019). Science, technology and innovation ecosystem transformation toward society 5.0. International Journal of Production Economics, 107460. https://doi.org/10.1016/j.ijpe.2019.07.033

Ghareb, M., \& Ahmed, A. (2018). Design and Implement Mobile Learning Application for Students in Higher Education. Asian Journal of Information Technology, 17. https://doi.org/10.3923/ajit.2018.177.188

Grunwitz, K. (2019). The future is Society 5.0. Computer Fraud \& Security, 2019(8), 20. https://doi.org/10.1016/S1361-3723(19)30087-9

Hamidi, H., \& Jahanshaheefard, M. (2019). Essential factors for the application of education information system using mobile learning: A case study of students of the university of technology. Telematics and Informatics, 38, 207-224. https://doi.org/10.1016/j.tele.2018.10.002

Helsper, E. J., \& Eynon, R. (2010). Digital natives: Where is the evidence? British Educational Research Journal, 36(3), 503-520. https://doi.org/10.1080/01411920902989227

Jahnke, I., \& Liebscher, J. (2020). Three types of integrated course designs for using mobile technologies to support creativity in higher education. Computers \& Education, 146, 103782. https://doi.org/10.1016/j.compedu.2019.103782

Judd, T. (2018). The rise and fall (?) of the digital natives. Australasian Journal of Educational Technology, 34(5). https://doi.org/10.14742/ajet.3821

Kadry, S., \& Ghazal, B. (2019). Design and Assessment of Using Smartphone Application in the Classroom to Improve Students' Learning. International Journal of Engineering Pedagogy (IJEP), 9(2), 17. https://doi.org/10.3991/ijep.v9i2.9764

Karakasidis, T. (2013). Virtual and remote labs in higher education distance learning of physical and engineering sciences. 2013 IEEE Global Engineering Education Conference (EDUCON), 798-807. https://doi.org/10.1109/EduCon.2013.6530198

Kattayat, S., Josey, S., \& J.V, A. (2017). Mobile Learning Apps in Instruction And Students Achievement. International Journal of Interactive Mobile Technologies (IJIM), 11(1), 143. https://doi.org/10.3991/ijim.v11i1.6420

Kemp, S. (2018). Digital in 2018: World's internet users pass the 4 billion mark. https://wearesocial.com/blog/2018/01/global-digital-report-2018

Kirschner, P. A., \& De Bruyckere, P. (2017). The myths of the digital native and the multitasker. Teaching and Teacher Education, 67, 135-142. https://doi.org/10.1016/j.tate.2017.06.001

Krull, G., \& Duart, J. M. (2017). Research Trends in Mobile Learning in Higher Education: A Systematic Review of Articles (2011 - 2015). The International Review of Research in Open and Distributed Learning, 18(7). https://doi.org/10.19173/irrodl.v18i7.2893

Kuntoro, R. D., \& Al-Hawamdeh, S. (2003). E-Learning in Higher Educational Institutions in Indonesia. Journal of Information \& Knowledge Management, 02(04), 361-374. https://doi.org/10.1142/S0219649203000553

Lestari, I., Maksum, A., \& Kustandi, C. (2019). Mobile Learning Design Models for State University of Jakarta, Indonesia. International Journal of Interactive Mobile Technologies (IJIM), 13(09), 152. https://doi.org/10.3991/ijim.v13i09.10987

Lipomi, D. J. (2020). Video for Active and Remote Learning. Trends in Chemistry, S2589597420300769. https://doi.org/10.1016/j.trechm.2020.03.003

Martín, A. J. L. (2003). Web-Based Remote Learning of Communication Systems: A Successful Experience. International Journal of Electrical Engineering \& Education, 40(3), 169-174. https://doi.org/10.7227/IJEEE.40.3.1

Nagy, K., \& Hajrizi, E. (2019). Building Pillars for Adapting Society 5.0 in Post-Conflict Countries. IFACPapersOnLine, 52(25), 40-45. https://doi.org/10.1016/j.ifacol.2019.12.443 
Ozdamar Keskin, N., \& Kuzu, A. (2015). Development and testing of a m-learning system for the professional development of academics through design-based action research. The International Review of Research in Open and Distributed Learning, 16(1). https://doi.org/10.19173/irrodl.v16i1.1613

Pereira, O. R. E., \& Rodrigues, J. J. P. C. (2013). Survey and analysis of current mobile learning applications and technologies. ACM Computing Surveys, 46(2), 1-35. https://doi.org/10.1145/2543581.2543594

Pimmer, C., Mateescu, M., \& Gröhbiel, U. (2016). Mobile and ubiquitous learning in higher education settings. A systematic review of empirical studies. Computers in Human Behavior, 63, 490-501. https://doi.org/10.1016/j.chb.2016.05.057

Rodriguez-Morales, A. J., Cardona-Ospina, J. A., Gutiérrez-Ocampo, E., Villamizar-Peña, R., Holguin-Rivera, Y., Escalera-Antezana, J. P., Alvarado-Arnez, L. E., Bonilla-Aldana, D. K., Franco-Paredes, C., HenaoMartinez, A. F., Paniz-Mondolfi, A., Lagos-Grisales, G. J., Ramírez-Vallejo, E., Suárez, J. A., Zambrano, L. I., Villamil-Gómez, W. E., Balbin-Ramon, G. J., Rabaan, A. A., Harapan, H., ... Sah, R. (2020). Clinical, laboratory and imaging features of COVID-19: A systematic review and meta-analysis. Travel Medicine and Infectious Disease, 101623. https://doi.org/10.1016/j.tmaid.2020.101623

Rusli, R., Rahman, A., \& Abdullah, H. (2020). Student perception data on online learning using heutagogy approach in the Faculty of Mathematics and Natural Sciences of Universitas Negeri Makassar, Indonesia. Data in Brief, 29, 105152. https://doi.org/10.1016/j.dib.2020.105152

Stat Counter Global Stats. (2019, 2020). Mobile Operating System Market Share Indonesia. https://gs.statcounter.com/os-market-share/mobile/indonesia

Sumarwati, S., Fitriyani, H., Azhar Setiaji, F. M., Hasril Amiruddin, M., \& Afiat Jalil, S. (2020). Developing Mathematics Learning Media Based on E-Learning using Moodle on Geometry Subject to Improve Students' Higher Order Thinking Skills. International Journal of Interactive Mobile Technologies (IJIM), 14(04), 182. https://doi.org/10.3991/ijim.v14i04.12731

Sung, Y.-T., Lee, H.-Y., Yang, J.-M., \& Chang, K.-E. (2019). The quality of experimental designs in mobile learning research: A systemic review and self-improvement tool. Educational Research Review, 28, 100279. https://doi.org/10.1016/j.edurev.2019.05.001

Thinyane, H. (2010). Are digital natives a world-wide phenomenon? An investigation into South African first year students' use and experience with technology. Computers \& Education, 55(1), 406-414. https://doi.org/10.1016/j.compedu.2010.02.005

Thompson, P. (2013). The digital natives as learners: Technology use patterns and approaches to learning. Computers \& Education, 65, 12-33. https://doi.org/10.1016/j.compedu.2012.12.022

Townsend, L., Wallace, C., Fairhurst, G., \& Anderson, A. (2017). Broadband and the creative industries in rural Scotland. Journal of Rural Studies, 54, 451-458. https://doi.org/10.1016/j.jrurstud.2016.09.001

VanTassel-Baska, J. (2014). Performance-Based Assessment: The Road to Authentic Learning for the Gifted. Gifted Child Today, 37(1), 41-47. https://doi.org/10.1177/1076217513509618

Viner, R. M., Russell, S. J., Croker, H., Packer, J., Ward, J., Stansfield, C., Mytton, O., Bonell, C., \& Booy, R. (2020). School closure and management practices during coronavirus outbreaks including COVID19: A rapid systematic review. The Lancet Child \& Adolescent Health, S235246422030095X. https://doi.org/10.1016/S2352-4642(20)30095-X

Yassine, A., Berrada, M., Tahiri, A., \& Chenouni, D. (2018). A Cross-Platform Mobile Application for Learning Programming Basics. International Journal of Interactive Mobile Technologies (IJIM), 12(7), 139. https://doi.org/10.3991/ijim.v12i7.9442

Yot-Domínguez, C., \& Marcelo, C. (2017). University students' self-regulated learning using digital technologies. International Journal of Educational Technology in Higher Education, 14(1), 38. https://doi.org/10.1186/s41239-017-0076-8 